\title{
The Results and Methodological Concerns about Pharmaco-Economic Evaluation in Anesthesia
}

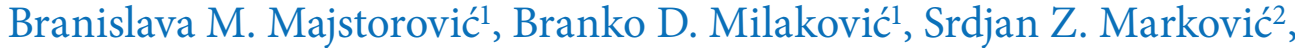 \\ Miloš S. Mijajlović 3 , Dragana A. Kastratović ${ }^{4}$ \\ ${ }^{1}$ Center of Anesthesiology and Reanimation, Clinical Center of Serbia, Belgrade, Serbia; \\ ${ }^{2}$ School of Medicine, University of Belgrade, Belgrade, Serbia; \\ ${ }^{3}$ Healthcare Center, Jagodina, Serbia; \\ ${ }^{4}$ Center of Clinical Pharmacology, Clinical Center of Serbia, Belgrade, Serbia
}

\section{SUMMARY}

Background Globalization and profitable health (cost/benefit) requires pharmacoeconomic evaluation of the costs in relation to effectiveness of the methods of treatment. The objective of this study was to analyze the cumulative costs of anesthesia in all surgical disciplines using the Activity-Based Costing (ABC) analysis.

Methods This work is a part of Phase IV clinical study. Retrospectively, for 2006, direct costs of anesthesia services were calculated: (1) personnel costs (salaries), (2) drugs and supplies, (3) other costs (analysis and apparatus) in the Institute of Anesthesiology and Resuscitation, Clinical Center of Serbia. The research group included all anesthetized patients of both genders and ofall ages. Summary data documented in the anesthesia department and databases of the Clinical Center of Serbia and the Republic Institute of Health Insurance were used. Numerical data were calculated and analyzed by computer programs Microsoft Office Excel 2003 and SPSS for Windows.

Results The results of direct costs showed that personnel costs accounted for $40 \%$, medicines and supplies $-31.80 \%$ and other costs $-28.20 \%$ of the funds. Anesthesia costs accounted for $10 \%$ (ABC analysis) of direct costs. Methodological dilemmas were related to the inaccuracy of anesthetic and surgical protocols, the classification of anesthetic and surgical services and the imperfection of computer data entry software. Basic hospital activities information should be more specific and precise. Clinical protocols of the anesthetized patients should be connected better with the Admission department, Intensive care units, Day surgical hospital and other departments. Database of the clinical drug pathway, Clinical protocols, Accounting Information Systems, and Hospital Management Information Systems should be precise, specific and managed in a better way.

Conclusions The costs of local and general anesthesia procedures are objectively low and numerous, what may be objectified by this pharmacoeconomic analysis. Those insufficiently informed call for "rationalization". The costs of drugs and supplies are real while all other costs are agreed upon, and accordingly, there is no possibility of cutting down the expenses within so small and restrictive health budget. The change of budget dynamics and education of control staff could be helpful.

Keywords: anesthesia; $A B C$ analysis; methodological concerns 


\section{INTRODUCTION}

Financed health systems free for patients are not economic reality any more. Contemporary health management requires profitable (cost/ benefit) health, which compares the costs and therapeutical effects of drugs, surgical procedures and estimates medical devices.

Physicians providing medical services, educated, authoritative and responsible for their actions, often have difficulties to adjust their humane motivation with the above-said reality.

Over decades, many countries have been implementing various forms of resource rationalization in order to maintain, promote and enable the accessibility of population treatment in the healthcare system. Globalization and development of knowledge, medical and information technologies provide opportunity for new methods of treatment. The modern therapeutical protocols call for establishment of multidisciplinary teams and partner-based doctor-patient relation during the course of treatment [1].

Anesthesia is a special medical discipline, which enables to perform diagnostic and surgical interventions. Anesthesia is involved in management of many diseases, but it does not treat any of them specifically. Besides general principles, anesthesia has developed some specific principles for different surgical disciplines. This is why anesthesia is organized as services, following and allowing development of surgical disciplines simultaneously with its progress.

Today in contemporary profitable, cost-benefit public health, it is necessary to estimate the costs and anesthesia effectiveness in teamwork and in multidisciplinary teams.

In our country and surrounding region, the hospital healthcare spends up to one half (38\%$50 \%)$ of a total resources intended for health [2, 3]. Data are obtained: (1) directly, simultaneously with clinical studies; (2) directly, retrospectively or prospectively from medical documents, by multiplication of measured consumed resources with the prices of "unit costs" obtained from the Financial Department of the given institution or official price lists; (3) virtually by computer simulation of costs and therapeutical effects for the specific time horizon, most frequently ten-year period (e.g., decision tree model, epidemiological model, regression model) [4]. Recommendation for specific therapy depends upon clinical benefit of such therapy, its cost-effectiveness and financial burden of national health budget.
The question arises: how to get as much as possible from the existing resources, and concurrently follow the introduction of new methods of treatment and modern technology. According to economic evaluations, commercial (fiscal) management of resources is based on evaluation of present health technologies and appraisal of rationality in therapeutical interventions Economic evaluations use methods that involve simultaneous analysis of therapeutical effect and prices, i.e., intervention costs. Economic evaluations should not be a replacement for judgment of medical experts! [5] By definition of evaluation, the amount of resources used for specific therapy is measured, and the costs and effects of alternative therapies that are considered are compared. It is insisted on financing the health services based on documented cost-effectiveness, where the effectiveness of treatment, therapies, surgical interventions, etc., are measured by the quality of lifetime (quality-adjusted life year - QALY), expected lifetime spent in health (disability-adjusted life year - DALY) and healthy-years equivalent (HYE) [6].

Due to above mentioned specifics of anesthesia, it is delicate to estimate its financial share in surgical treatment today. Prerequisites are precise and detailed clinical protocols of anesthesia and respective computer databases. Real costs are difficult to calculate because only the costs of drugs, and medical and nonmedical supplies are easily available and transparent. Other costs are fixed and not dependable upon the number of patients receiving the given service, but they are formed under the contract of contracting parties. In traditional Volume Based Costing (VBC), the costs of one medical service or hospital unit are measured, using single indicator (the number of working hours, patients, etc.). The results are often rough, complicated and inaccurate. The work of anesthesiologist was measured by the number of anesthesias and time spent in the operating room, while other anesthesiological work aspects, such as preanesthetic visit, preparations for anesthesia, transport of patient, stay in the Intensive therapy unit (ITU), consultations, etc., were neglected [7, 8].

Activity Based Costing (ABC) is a methodological procedure for measurement of all anesthesia-related costs. In this method, hospital costs are divided by activities as follows: consumption in the clinical centers (medical and surgical costs, costs within infectious diseases, etc.), costs of clinical unit support (anes- 
thesiology, clinical pharmacology, biochemical laboratories, radiology, etc.) and the costs of the outpatient services (emergency, polyclinic, day surgery, rehabilitation, dialysis, etc.). The costs of anesthesiology are interpreted as clinical support costs [9] to surgery as the center of clinical consumption. The introduction of this methodology of cost calculation would be helpful to introduction of the financial system Diagnosis Related Group (DRG) [10,11], which has been applied in developed European Union countries. A special Accounting Information Systems (AIS) and Hospital Management Information System (HMIS) [12] are necessary for DRG.

The objective of our study was to analyze the cumulative direct costs of anesthesia as a part of surgical costs.

\section{METHODS}

This study is a part of academic (noncommercial) phase IV pharmacoeconomic retrospective-prospective study, carried out in compliance with the EU Directives of clinical trials [13]. Upon approval by the Ethics Board (faculty of Medicine, University of Belgrade, entry file 470/ IV7), we calculated direct costs of anesthesiological services in the Institute of Anesthesia and Reanimation, Clinical Center of Serbia (CCS), for 2006, as follows: (1) medical staff salaries (personnel costs); (2) anesthetics, drugs, and medical and nonmedical supplies, and (3) other: analysis required for anesthesia and apparatuses (anesthesia machines, respirators, etc.). Study group included all anesthetized patients of both genders and all ages. The consumption of anesthetics and other medicaments, medical and non-medical supplies according to the data obtained from the individual anesthesia lists and accounting anesthesia lists was submitted to the Center for Social Medicine and Medical Statistics, CCS. Cumulative data of Anesthesia department activities, documented in CCS database, such as the number of general and local anesthesia and anesthesia services, and value and number of apparatuses used in anesthesia, were applied. General data of surgical work were computed according to CCS data [9], such as the number of operating rooms, hospital days, surgical interventions and, where missing, according to data of anesthesia service packages by "unit costs" of the Republic Institute of Public Health Care. Numerical data were computed and analyzed by Microsoft Office Excel 2003 and SPSS for Windows.

\section{Study limitations}

The calculation of medical costs of surgical service, as a center of clinical consumption, did not include the indirect costs of non-medical services such as patient's transport to emergency anesthesiological and admission surgical out-patient clinics. In addition, the following indirect costs were not included: social loss because of decreased work contribution of patient due to his/her disease, inability or death; nonmaterial costs were not calculated/analyzed as follows: "psychological cost" of disease or therapy (pain, discomfort, fear, etc.).

\section{RESULTS}

The CCS had 56 operating rooms, 1,097 surgical beds, out of which 199 were located in the Emergency Surgical Service. Mean time of treatment was 10.65 days. The anesthesiologists rendered 70,195 anesthesia services in 32,267 patients for 46,738 diagnostic and surgical interventions. In relation to general patient's condition and specificity of the surgical intervention, general, local anesthesia and anesthesiological procedures are combined for the same surgical intervention (Table 1 ).

Table 1. Number of anesthesia services in the Clinical Center of Serbia, Belgrade, in 2006

\begin{tabular}{ccccc}
$\begin{array}{c}\text { Department of Anesthesia } \\
\text { and Reanimation }\end{array}$ & $\begin{array}{c}\text { No. of general } \\
\text { anesthesia }\end{array}$ & $\begin{array}{c}\text { No. of local } \\
\text { anesthesia }\end{array}$ & $\begin{array}{c}\text { Anesthesia } \\
\text { procedures }\end{array}$ & $\begin{array}{c}\text { Anesthesia } \\
\text { services }\end{array}$ \\
Number of services & 33.187 & 20.614 & $20.614^{\star}$ & 70.195 \\
$\%$ & 47 & 23 & 30 & 100 \\
\hline
\end{tabular}

* Anesthesiological services include different types and techniques of general and local anesthesia and anesthetic procedures: analgesia and other procedures. Other procedures are controlled hypotension, cannulation of the arterial and venous vessels, preparation and connection of blood pressure monitoring systems, placement of the infusion pumps, etc. 
The obtained cumulative results of direct costs of anesthesia services are presented in Table 2.

Annual gross salary of an anesthesiologist, with calculated 40 overtime hours and anesthetist with secondary education was RSD 491,536.00 ( $€ 8,876)$ and RSD 258,137.00 $(€ 4,461.27)$, respectively. The costs of managing officers, staff with teaching, scientific and professional titles, continuous education and overtime of nurses were not calculated in personnel costs, and they all should be included.

In our study, anesthetics and other drugs consumed a little bit more than $30 \%$ of a total direct costs of anesthesia, accounting for 5.93\% of resources intended for CCS drugs (Table 3). The costs of blood and antibiotic use were not analyzed because these services are the responsibility of other departments [14].

Other costs - laboratory tests required for anesthesia (blood count) and other biochemical analyses, prothrombin time (PT), partial prothrombin time (PTT), lung $\mathrm{x}$-ray and ECG - consumed 10\%, and apparatuses and other machines $18 \%$ of funds. According to protocol, the analyses are repeated several times in urgent and highly specialized surgical operations in the ITU that additionally increases the expenses.

Depreciated medical equipment costs (anesthesia machines, laryngoscopes, Ambu balloons, monitors, defibrillators, bronchial aspirators, infusion pumps for continuous intravenous injection, Ventilog (respirators), etc., were calculated according to costs as per day of accounting inventory for 2006.

In relation to personnel surgical costs, personnel anesthesia costs were lower probably due to lesser number of anesthesiologists and consequently lesser number of duty hours in home surgical clinics. The consumption of drugs and supplies was lower in surgical disciplines, while other costs were higher because of sophisticated machines in operating theaters.

\section{DISCUSSION}

CCS is the biggest clinical center in Serbia. The Institute of Anesthesia and reanimation had 112 employed anesthesiologists, allocated to surgical institutions. In our opinion, the reason for varying number of anesthesia services in relation to surgical interventions would be inaccurate documentation and uneven classification definitions of interventions. For example, one
Table 2. Direct costs of services in the Department of Anesthesia and Reanimation, Clinical Center of Serbia, Belgrade, in 2006

\begin{tabular}{lc} 
Department of Anesthesia and Reanimation & Direct costs \\
\hline Personnel costs & $40.00 \%$ \\
Anesthetics, drugs + supplies & $31.80 \%$ \\
Other: analyses + apparatuses & $28.20 \%$ \\
Total & $100.00 \%$ \\
\hline
\end{tabular}

Table 3. Direct costs of services in the Department of Surgery, Clinical Center of Serbia, Belgrade, in 2006

\begin{tabular}{lc} 
Department of Surgery & Direct costs \\
\hline Personnel costs & $43.92 \%$ \\
Anesthetics, drugs + supplies & $15.46 \%$ \\
Other: analyses + apparatuses & $41.72 \%$ \\
Total & $100.00 \%$ \\
\hline
\end{tabular}

operation may be divided by work elements into several interventions or be a combination of several interventions by different classifications in the same procedure. The problem of inefficient record keeping has arisen, including the clinical protocols of anesthesia, where there is no financial separation of repeated anesthesia for repeated surgical intervention due to surgical complications. The problem of unlisted (not recorded) data or inadequate methodology of record keeping is a constant even in the countries where such recording protocol is longer and better [15].

The obtained personnel costs accounted for $40 \%$ of direct costs, in distinction from other studies where they were $30 \%$ of costs for doctors - anesthesiologists, excluding secondary qualified medical staff, without calculation of other fees $[16,17]$. The administrative pressure to anesthesia sector in view of rationalization primarily refers to salaries, and then to other elements of direct costs. The wages are not adequate to work in conditions of inflation and transition. That is why we think that there is no room for their cutting down. In Serbia, personal income is not in relation to the number of treated patients in the secondary and tertiary healthcare, in distinction from primary health care and stomatology where the method of payment of fixed amount to physician per patient (capitation) has been introduced. Different methods of payment to physicians: by service, the list of patients who choose their doctor, or salaries based on other university-degree personnel income, excludes the possibility of comparison of these costs. 
Medicines and medical supplies are transparent, real costs which are easily and frequently controlled. According to our study, anesthetics and other drugs accounted for $30 \%$ of an overall direct costs of anesthesia, figuring out at $5.93 \%$ of all resources intended for medication in the CCS. At the CCS level, drug expenses were RSD $1,405,633,000$ or $15.46 \%$ of the costs included in the analysis of operative costs. The obtained results are compatible with other studies, where out of overall resources for hospital drugs, $5 \%$ are allocated for anesthesia [18]. Out of anesthetics and other drugs used in anesthesia, the most expensive are inhalation anesthetics and muscular relaxants, followed by general anesthetics (propofol) and intravenous solutions [19]. The Institute of Anesthesiology and Reanimation uses the method of minimal gas flow (oxygen and nitrogen suboxide) in general anesthesia and applies local anesthesia, whenever possible, for rationalization of funds.

Numerous pharmacoeconomic studies addressing the theoretical analysis of costs and potential benefit of different types and anesthesia techniques have been published. The results are not final and anesthesia departments keep on searching for cutting down the costs.

Used supplies accounted for $3 \%$ of the time, what is not real because of inaccurate return of the issued equipment to surgical departments. Other studies report the costs of supplies of $2-10 \%[20]$.

The costs of laboratory analyses and apparatuses were $28.20 \%$. The costs of apparatuses were minimal because these machines were not renewed in the last five years and because of inadequate methodology of machine price amortization! In fiscal policy, amortization value of anesthesia machines loses its monetary value after five-year utilization [21].

The expenses of "hotel accommodation" [22], which are generally a part of hospital daily costs, were not calculated in other costs, but they should be definitely included as such. In principle, anesthesia for surgical intervention is applied only once but the effect of anesthetics modifies the state of consciousness from several to 24 hours afterwards, and the intensive monitoring of vital functions is required in the postanesthetic/recovery rooms and/or for a longer period of time in vitally threatened patients in ITU, which is all the responsibility of an anesthesiologist and surgeon.

On average in 2006, the costs per hospitalized patient and per hospital day reached RSD
76,600 and RSD 7,115, respectively [9]. Average costs per general anesthesia were around RSD 30,000 ( $€ 379.75$ or USD 500.17) [23]. The anesthesia costs as the center of clinical consumption will increase surgical costs by $10 \%$. The studies $[24,25]$ have concluded that the individual costs of anesthesiological services are low, but collectively they are high due to versatility of services.

Indirect costs, defined as loss of income which would be realized if a patient was capable of working, do not have any significance due to, most often, one-time anesthesia [26]. A methodological question arises, what is the effect of general anesthesia and surgical intervention, respectively, to indirect costs during hospital treatment. The effect of anesthetics and other medication used in anesthesia change the state of consciousness up to 24 hours. We, therefore, defend our attitude that the stay of patients in the Intensive therapy unit is a responsibility of an anesthesiologist. Since the savings of direct costs in anesthesia are almost impossible in CCS [27], the authors would like to emphasize, although it is not the subject of this study, that in preparation of financial statements, the difference between the costs of patient management and infrastructure must be made. Indirect costs imply auxiliary medical functions. Nonclinical indirect costs are as follows: hotel accommodation expenses (hospital day), sterilization, administration, security, utilities (maintenance, transport, depreciation, repayment of loans and loans, future investments), which all have to be economically observed. The wages are small, budget for drugs, medical devices and supplies is minimal, and indirect costs are uncountable and the only area where the cost analysis in terms of cost-effectiveness may be carried out.

There has been a trend of accelerated technological progress in medicine, i.e. $20 \%$ more than expected accounting annual values [9], and, therefore, the authors point to diminished likelihood of rendering top-quality health service even in the tertiary medical institutions, in spite of highly-educated doctors [28].

\section{Perspectives}

Methods of pharmacoeconomic evaluations that should be done are as follows: (1) Cost minimization analysis (CMA) of general or local anesthesia for particular, same surgical inter- 
vention, if applicable, (2) Cost-effectiveness analysis (CEA), (3) Cost-utility analysis (CUA), or cost/better quality of life, and (4) Costbenefit analysis (CBA).

The analysis of incremental effectiveness (cost balance is divided by their effect balance) yields coefficient showing the cost of additional unit of effectiveness of one therapy (anesthesia) in relation to another. The choice of therapy, anesthesia or mode of treatment depends on the value adopted as the "ceiling" by the authorities. All the aforementioned represents a huge number of studies that should be performed in future.

\section{CONCLUSIONS}

Health costs increase, particularly in sophisticated fields of medicine such as anesthesia. Within the surgical costs, perioperative anesthesia accounts for $10 \%$ (ABC analysis). Our experience has shown that personnel costs "consume" the biggest part of direct costs of resources (40\%), followed by drugs and supplies (32\%) and other costs: analyses and apparatuses (28\%). The cost of anesthetics and drugs, especially new, short-acting inhalation anesthetics and intravenous analgetics and neuromuscular blockers has gained considerable attention. In circumstances of small and restrictive national budget for public health, there is no space for cutting down the personnel costs, anesthetics and drugs as well as other direct costs of anesthesia. The results are not final and anesthesia departments keep on looking for modes of costs reduction.

In order to avoid methodological dilemmas in pharmacoeconomic studies in anesthesia, we consider that: (1) basic information on hospital activities should be more specific for the significance of $\mathrm{ABC}$ analysis in future (DRG); (2) database should be more accurate and specific for establishing and functioning of the Accounting Information Systems (AIS) and Hospital Management Information Systems (HMIS); and (3) pharmacoeconomic studies should follow the work of clinics on everyday basis, and the study results should be respected and implemented.

\section{Conflict of Interest Statement}

The authors certify that there are no potential conflicts of interest.

\section{REFERENCES}

1. Pettignano R, Caley SB, McLaren S. The health law partnership: adding a lawyer to the health care team reduces system costs and improves provider satisfaction. J Public Health Manag Pract. 2012; 18(4):E1-3.

2. Bredenkamp C, Gragnolati M. Sustainability of healthcare financing in the Western Balkans: an overview of progress and challenges. Policy Research Working Paper 4374. Washington, DC: The World Bank, European and Central Asia Region, Human Development Department; 2007.

3. The World Bank. Health, Nutrition and Population (HNP) Discussion Paper. Provider Payment Reforms: Policy Note. Washintong DC: The World Bank; 2007.

4. Novaković T. Priručnik za farmakoekonomske evaluacije. Beograd: Crown Agents Project; 2006.

5. Al-Janabi H, Flynn TN, Coast J. QALYs and carers. Pharmacoeconomics. 2011; 29(12):1015-23.

6. Griffiths UK, Anigbogu B, Nanchahal K. Economic evaluations of adult weight management interventions: a systematic literature review focusing on methods used for determining health impacts. Appl Health Econ Health Policy. 2012; 10(3):145-62.

7. Schuster M, Standl T, Wagner JA, Berger J, Reimann H, Am Esch JS. Effect of different cost drivers on cost per anesthesia minute in different anesthesia subspecialties. Anesthesiology. 2004; 101(6):1435-43.

8. Berry M, Schüpfer G, Martin J, Bauer M, Denz C Bender HJ, Schleppers A. Controling and reporting in operating room managment:analysis of the state and development. Anaesthesist. 2008; 57(3):269-74.

9. TA for Capcity Building for Tertiary Care Services Republic of Serbia. A project funded by the European Union. Belgrade: Ministry of Health of the Republic Serbia, European Investment Bank, Sorfeco; 2006.

10. O’Reilly J, Serdén L, Talbäck M, McCarthy B; EuroDRG group. Performance of 10 European DRG systems in explaining variation in resource utilization in inguinal hernia repair. Health Econ. 2012; 21 (2):89-101.

11. Franz D, Schemmann F, Selter DD, Wirtz DC, Roeder N, Siebert H, Mahlke L. Orthopedic and trauma surgery in the German DRG system. Recent developments. Unfallchirurg. 2012; 115(7):656-62.

12. Zhang NJ, Seblega B, Wan T, Unruh L, Agiro A, Miao L. Health information technology adoption in u.s. Acute care hospitals. J Med Syst. 2013; 37(2):990-7.

13. European Parliament and the Council of the European Union Directive 2001/20/EC of the European Parliament and of the Council on the approximation of the laws, regulations and administrative provisions of the member states relating to implementation of good clinical practice in the conduct of clinical trials on medical products for human use. May, 2001. Available from: http://www.eortc.be/services/ doc/clinical-eu-directive-04-april-01.pdf (accessed May 16, 2003).

14. Kastratović DA, Djukić VB, Majstorović BM, Komrska JJ, Gajić MM, Marković SZ. Antibiotic consumption monitoring at the Institute of Otorhinolaryngology and Maxillofacial surgery Clinical Center of Serbia in 2001-2003. Vojnosanit Pregl. 2005; 62(7-8):551-5. 
15. Negrini DA, Kettle L, Sheppard GH, Mills DL. The cost of a hospital ward in Europe: is there a methodology available to accurately measure the costs? J Health Organ Manag. 2004; 18(3):195206.

16. Grbić D, Terzić Z, Vuković D. Financing health care system. In: Support Reform of the Health Care System and Achieve Sustainable Funding. Belgrade: Institute of Social Medicine, Faculty of Medicine, University of Belgrade; Open Society Fund Serbia; 2004. p.71-105.

17. Uredba o koeficijentu za obračun $\mathrm{i}$ isplatu plata zaposlenih u javnim službama. Službeni glasnik Republike Srbije br. 106/2006.

18. Majstorović BM, Kastratović DA, Milaković BD, Marković SZ, Mijajlović MS, Vučović DS. Troškovi primene anestetika i drugih lekova u anesteziji. Med Pregl. 2012; 65(1-2):30-4.

19. Meyer JT, Reissmann H, Schuster M, Raetzell M, Rösler L, Petersen F, et al. Realisation of material costs in anaesthesia. Alternatives to the reimbursement via diagnosis-related groups. Anaesthesist. 2007; 56(4):353-62, 364-5.

20. Pavey TG, Anokye N, Taylor AH, Trueman P, Moxham T, Fox KR, et al. The clinical effectiveness and cost-effectiveness of exercise referral schemes: a systematic review and economic evaluation. Health Technol Assess. 2011; 15(44):i-xii, 1-254.

21. De Castro V, Puizillout JM, Baguenard P, Wioland Y, Billard V, Bourgain JL. Survey and budgetary impact of anaesthesia machines failures. Ann Fr Anesth Reanim. 2003; 22(6):499-504.
22. Sinclair DR.Discounted cash flow of anesthesia information management systems. J Clin Anesth. 2012; 24(7):603-4.

23. Majstorović BM, Simić S, Milaković BD, Vučović DS, Aleksić VV. Descriptive analysis of work and trends in anesthesiology from 2005 to 2006: quantitative and qualitative aspects of effects and evaluation of anesthesia. Srp Arh Celok Lek. 2010; 138(9-10):624-31.

24. Majstorović BM, Kastratović DA, Vučović DS, Milaković BD, Miličić BR. Operating cost analysis of anesthesia:activity based costing (ABC analysis). Srp Arh Celok Lek. 2011; 139(7-8): 501-8.

25. McIntosh CA, Macario A. Managing quality in an anesthesia department. Curr Opin Anaesthesiol. 2009; 22(2):223-31.

26. Majstorović BM, Vučović DS, Milaković BD, Mikov MM, Mijajlović MS, Marković SZ, et al. The analysis of direct costs in anesthesia. Journal of Pharmacy Research. 2011; 4(10):3520-4.

27. Majstorović BM, Milaković BD, Kastratović DA, Miličić BR, Vučićević VR. Reductions in anesthesia direct costs is not the right way for rationalization of anesthesia costs. Med Pregl. 2012; 65(910):421-7.

28. Kastratović DA, Radošić NN, Milaković BD, Tomić SD, Nešić VS, Marković SZ. Anesthetic dose correction in hospital pharmacology using bispectral index monitoring technology. Med Pregl. 2012; 65(5-6):228-32. 


\title{
Rezultati i metodološke nedoumice farmakoekonomskih procena u anesteziji
}

\author{
Branislava M. Majstorović1, Branko D. Milaković1 ${ }^{\text {, Srđan Z. Marković }}{ }^{\text {, }}$ \\ Miloš S. Mijajlović ${ }^{3}$, Dragana A. Kastratović ${ }^{4}$ \\ ${ }^{1}$ Centar za anesteziologiju i reanimatologiju, Klinički centar Srbije, Beograd, Srbija; \\ ${ }^{2}$ Medicinski fakultet, Univerzitet u Beogradu, Beograd, Srbija; \\ ${ }^{3}$ Dom zdravlja, Jagodina, Srbija; \\ ${ }^{4}$ Centar za kliničku farmakologiju, Klinički centar Srbije, Beograd, Srbija
}

\section{KRATAK SADRŽAJ}

Uvod Globalizacija i profitabilno (tzv. cost-benefit) zdravstvo obuhvataju farmakoekonomsku procenu troškova u odnosu na efikasnost metoda lečenja bolesnika. Cilj rada je bila analiza zbirnih troškova anestezija u svim hirurškim disciplinama metodom obračuna troškova prema aktivnostima (engl. activity based costing $-A B C$ ).

Metode rada Rad je deo akademske studije IV faze. Retrospektivno smo za 2006. godinu izračunali direktne troškove anestezioloških usluga: 1) lične troškove (plate), 2) troškove za anestetike i lekove, medicinski i nemedicinski materijal i 3) ostalo - troškove analiza i aparata u Institutu za anesteziju i reanimaciju Kliničkog centra Srbije u Beogradu. Istraživačka grupa obuhvatila je sve anestezirane bolesnike oba pola i svih starosnih dobi. Korišćeni su zbirni podaci odeljenja anestezije dokumentovani u bazama podataka Kliničkog centra Srbije i Republičkog zavoda za zdravstveno osiguranje. Numerički podaci su računati i analizirani kompjuterskim programima Microsoft Office Excel 2003 i SPSS for Windows.

Rezultati Dobijeni rezultati su pokazali da lični dohodak učestvuje sa $40 \%$, lekovi i materijal sa $31,80 \%$, a ostali troškovi sa $28,20 \%$ direktnih troškova u anesteziji. U okviru hirurških troškova, troškovi anestezije učestvuju sa 10\% (ABC analiza). Metodološke nedoumice se odnose na nepreciznost anestezioloških i hirurških protokola, klasifikaciju anestezioloških i hirurških usluga, kao i na nesavršenost kompjuterskog softvera prilikom unošenja podataka. Osnovne informacije o bolničkim aktivnostima bi trebalo da budu određenije i preciznije. Klinički protokoli anesteziranih bolesnika mogu biti bolje povezani s prijemnom ambulantom, odeljenjima, jedinicama intenzivne nege i dnevnim hirurškim bolnicama. Baze podataka Kliničkog puta leka, Knjigovodstvenog informacionog sistema i Upravljačkog bolničkog informacionog sistema trebalo bi da budu bolje vođene, precizne i specifične.

Zaključci Troškovi lokalne i opšte anestezije i anestezioloških procedura su objektivno mali i mnogobrojni, što se objektivizira ovakvom farmakoekonomskom analizom. Nedovoljno upućeni zahtevaju „racionalizaciju“. Troškovi lekova i materijala su realni, a svi ostali troškovi ugovoreni, te nema mogućnosti za smanjenje troškova unutar malog i restriktivnog budžeta za zdravstvo. Promena budžetske dinamike i edukacija kadrova koji vrše kontrolu državnog aparata bi mogle pomoći.

Ključne reči: anestezija; $A B C$ analiza; metodološke nedoumice 